\title{
EDITORIAL
}

\section{THE AGEING EYE}

It is in the eyesight that everyone is first made aware of the inevitability of the ageing process. Try as one might it is impossible to stem its tide and we all have to wear spectacles in time if we wish to see clearly. Ageing in the eye is not however confined to the inability to accommodate; there are changes which occur in all the ocular tissues. As was mentioned in the discussion during the Cambridge Ophthalmological Symposium the changes are such that if we live to 140 we should all be almost blind. Much is still to be learned about the mechanisms of ageing not only in the eye but in the body as a whole. These mechanisms are discussed in this issue together with what is known about the ageing mechanisms in both eye and brain. How often has the ophthalmologist heard a patient say "Sight is so precious"? So it is, if one is about to lose it. If we have a clearer understanding of the mechanisms of ageing we might be able to do something to alleviate the ravages of time in our patients.

P. G. Watson F.R.C.S.

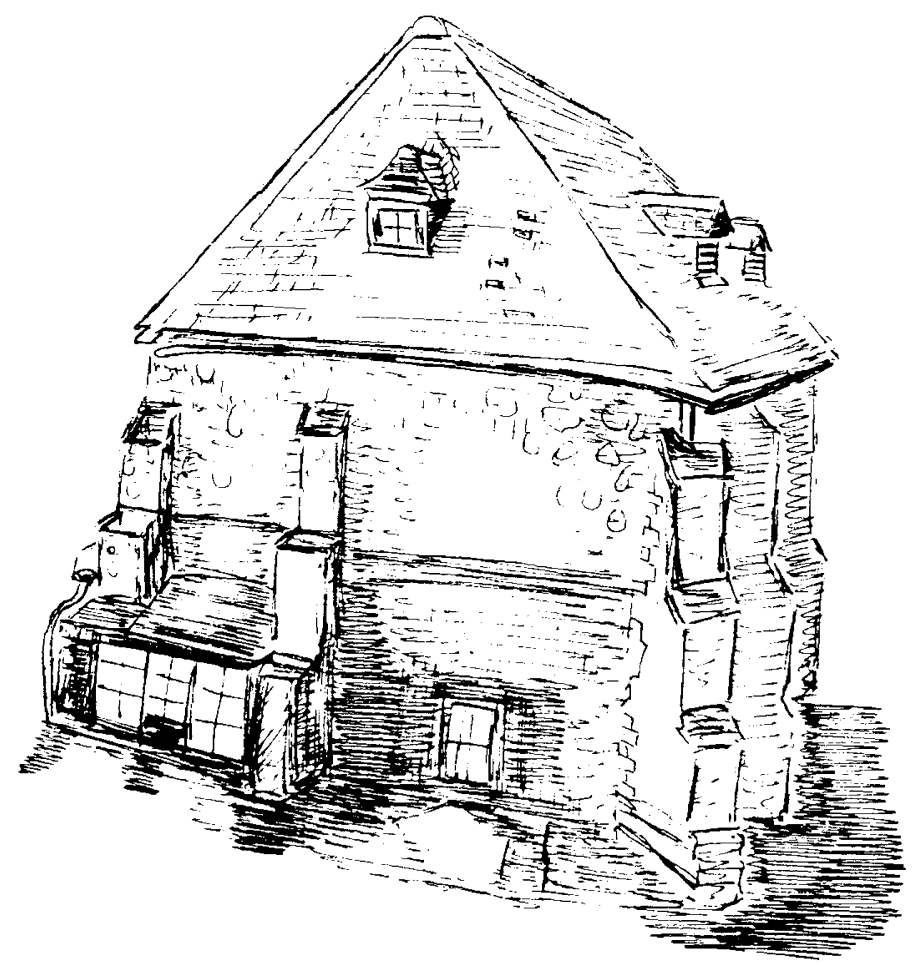

STENHUSET

senere kaldet Pythagoras School

bygget 1200 , privatbolis, kloster, nu St John's College,

Cambridge 5/9/1984

set fra Cripps Building nr. H23.

Acknowledgement to Professor dr. med. Mogens S. Norm, Denmark 